\title{
Genetic diversity in populations of Slovak Spotted cattle based on single nucleotide polymorphisms analyses*
}

\author{
Nina Moravčíková ${ }^{凶}$, Anna Trakovická and Alica Navrátilová \\ Department of Animal Genetics and Breeding Biology, Slovak University of Agriculture in Nitra, Nitra, The Slovak Republic
}

The aim of this study was to identify SNPs in leptin (LEP), leptin receptor (LEPR) and growth hormone (GH) genes in order to analyze genetic diversity of Slovak Spotted cattle. The total numbers of blood samples were taken from 353 Slovak Spotted cows originating from four farms. Genomic DNA was isolated by phenol-chloroform extraction method and analyzed by PCR-RFLP method. After digestion with restriction, enzymes were detected in whole population of cow's alleles with frequency: LEP/Sau3AI A 0.84 and B $0.16( \pm 0.0152) ;$ LEPR/BseGI $C 0.95$ and $T 0.05( \pm 0.0089)$ and $\mathrm{GH} /$ Alul $L \quad 0.70$ and $V$ $0.30( \pm 0.0188)$. Based on the observed vs. expected genotypes frequencies populations across loci were in Hardy-Weinberg equilibrium $(P>0.05)$. Predominant for SNP LEP/Sau3AI was AA genotype (0.70), for SNP LEPR/ T945M CC genotype (0.91), and LL genotype (0.48) was most frequent for SNP GH/Alul. The observed heterozygosity of SNPs across populations was also transferred to the low or median polymorphic information content 0.24 (He 0.28), 0.08 (He 0.09) and 0.33 (He 0.47) for LEP, LEPR and GH genes, respectively. Within genetic variability estimating negative values of fixation indexes FIS $(-0.09-0.05)$ and FIT $(-0.07-0.03)$ indicating heterozygote excess were observed. The value of FST indexes $(0.018-0.023)$ shows very low levels of genetic differentiation in allele frequencies of loci among evaluated subpopulations. The low values of genetic distances (0.0018-0.0159) indicated high genetic relatedness among animals in subpopulations caused probably by common ancestry used in breeding program at farms.

Key words: cattle, growth hormone, leptin, leptin receptor, polymorphism

Received: 15 October, 2013; revised: 06 December, 2013; accepted: 06 December, 2013; available on-line: 29 December, 2013

\section{INTRODUCTION}

Leptin and its receptor or growth hormone, as molecules affecting phenotypes of different traits in livestock, can be used as a genetic marker for enhancing the productivity of cattle and is also potential candidate for marker assisted selection in breeding strategies. Variation at DNA level contributes to the genetic characterization of livestock populations. Molecular genetics techniques currently available allow direct genotyping for candidate genes using PCR. Leptin (LEP) is a polypeptide hormone synthesized predominantly in the adipose tissue and affects a number of processes in the body. It is involved in maintaining the energy equilibrium by controlling food intake and energy expenditure, as well as in regulating reproductive functions and immune re- sponse (Zhang et al., 1994). Leptin appears to affect the central reproductive axis through its own receptors and the neurotransmitter, neuropeptide Y. Leptin affects also the secretion of various pituitary hormones, including $\mathrm{GH}$. The leptin gene is highly conserved across species, and is located on bovine chromosome $4 \mathrm{q} 32$. Its DNA sequence has more than 15000 base pairs and contains three exons, which are separated by two introns (Stone et al., 1996). Leptin is encoded by a single transcript of about 4.5 bp expressed primarily by adipose tissue. In cattle, leptin is expressed in the rumen, abomasums and duodenum before weaning, but only in the duodenum after weaning. The ruminant mammary epithelial cells also synthesize leptin during pregnancy and during established lactation (Leury et al., 2003). SNP LEP/Sau3AI is situated in the second intron and results in amino acid change at position 2059 of the protein chain (cytosine, $\mathrm{C}$ to thymine, T). Effects of leptin are exerted trough six receptors isoforms, but only its longest form (LEPRb) is fully functional and responsible for most hormone physiological functions of leptin (Tartaglia, 1997). A widespread expression of LEPR-b suggests that although most of leptin actions are mediated centrally, at the level of hypothalamus, it may also act in many peripheral tissues, including gonadal tissues (Silva et al., 2002). LEPR gene is located on bovine chromosome 3. The leptin receptor gene consists of 20 exons divided over $1.75 \mathrm{Mb}$. Inside LEPR gene, Liefers et al. (2004) described a missense mutation T945M. It is a cytosine to thymine base substitution at position 115 in exon 20, which results in a substitution of the amino acid (threonine, $\mathrm{T}$ to methionine, M) at residue 945 of leptin. Bovine growth hormone $(\mathrm{GH})$ is a single chain polypeptide produced in the anterior pituitary gland under the hypothalamic controls of two hormones: growth hormone releasing factor, which increases the secretion of GH, and somatotropin release-inhibiting factor which inhibits its secretion (Nicoll et al., 1986). In ruminants, $\mathrm{GH}$ is known to be responsible for galactopoesis and for the persistency of lactation. Because it's necessary for tissue growth, fat metabolism and homeorhesis, thus, it has an important

\footnotetext{
e-mail: nina.moravcikova1@gmail.com

*Presented at the 5th Central European Congress of Life Sciences "EUROBIOTECH 2013", Kraków, Poland.

"Abbreviations: FIS, FIT, FST, Wright's fixation indexes; GH/Alul, name of single nucleotide polymorphism in growth hormone gene; $\mathrm{GH}$, growth hormone; He, heterozygosity; Ho, homozygosity; LEP, leptin; LEPR, leptin receptor; LEP/Sau3AI, name of single nucleotide polymorphism in leptin gene; LEPR/T945M, name of single nucleotide polymorphism in leptin receptor gene; $\mathrm{Ne}$, effective allele number; PIC, polymorphic information content; PCR, polymerase chain reaction; RFLP, restriction fragment length polymorphism; SNP, single nucleotide polymorphism; Sau3Al, BseGl, Alul, restriction enzymes; TBE, electrophoresis buffer
} 
role in reproduction, lactation and normal body growth (Svennersten-Sjaunja \& Olsson, 2005). GH gene with approximately 1800 bp length, five exons and four introns is a part of multiple gene family that contains prolactin and placental lactogenes and assigned with chromosome region $19 \mathrm{q} 26$ in bovine genome. Flanking repeat sequences of $\mathrm{GH}$ gene regulate the expression of a gene. Lucy et al. (1993) reported a polymorphic site for AluI restriction endonuclease, localized in exon 5 in bovine GH gene and characterized by the substitution of cytosine for guanine at position 2,141 caused an amino acid change from leucine to valine at residue 127.

The aim of this study was to detect SNPs in genes encoding leptin, leptin receptor and growth hormone, and analyses of genetic diversity and structure of Slovak Spotted cows populations based on alleles and genotypes frequencies of these genetic markers.

\section{MATERIAL AND METHODS}

Animals and DNA extraction method. Biological samples were collected from 353 Slovak Spotted cows originating from four farms. Genomic DNA for genotyping was extracted from blood samples with isolation kit NucleoSpin Blood (Macherey-Nagel). DNA concentrations were estimated by spectrophotometer measuring the optical density at wave length of $260 \mathrm{~nm}$.

Analyses of single nucleotide polymorphisms. Genotype analyses were performed using the polymerase chain reaction-restriction fragment length polymorphism (PCR-RFLP) method. A 422 bp fragment of intron 2 in bovine LEP gene was amplified by PCR using forward and reverse primers according to Liefers et al. (2002) and PCR products of exon 20 of the bovine LEPR gene sequence with length 197 bp were carried according Almeida et al. (2008). The polymerase chain reaction was performed in a $25 \mu$ reaction mixtures, containing: 1 x PCR buffer $\left(\mathrm{NH}_{4}\right)_{2} \mathrm{SO}_{4}, 1.5 \mathrm{mM} \mathrm{MgCl}, 2 \mathrm{mM}$ dNTPs, $8 \mathrm{pM}$ primers (Generi-Biotech), 1 U Tag DNA polymerase (Fermentas), 50 ng genomic DNA and $1 \times$ PCR buffer $\left(\mathrm{NH}_{4}\right)_{2} \mathrm{SO}_{4}, 2 \mathrm{mM} \mathrm{MgCl}, 2 \mathrm{mM}$ dNTPs, 8 pM primers (Generi-Biotech), 1 U Tag DNA polymerase (Fermentas), $50 \mathrm{ng}$ genomic DNA for the LEP and LEPR gene, respectively. Thermal cycling conditions included: an initial denaturation step at $95^{\circ} \mathrm{C}$ for $5 \mathrm{~min}$, followed by 35 cycles of $95^{\circ} \mathrm{C}$ for $30 \mathrm{sec}, 55^{\circ} \mathrm{C}$ for $20 \mathrm{sec}, 72^{\circ} \mathrm{C}$ for 30 sec and a final extension at $72^{\circ} \mathrm{C}$ for $7 \mathrm{~min}$; at $94^{\circ} \mathrm{C}$ for $3 \mathrm{~min}$, followed by $40 \mathrm{cycles}$ of $94^{\circ} \mathrm{C}$ for $30 \mathrm{sec}, 53^{\circ} \mathrm{C}$ for $1 \mathrm{~min}, 72^{\circ} \mathrm{C}$ for $30 \mathrm{sec}$ and extension at $72^{\circ} \mathrm{C}$ for 5 min for the LEP and LEPR genes, respectively. A 428 bp fragment of exon 5 in bovine GH gene was amplified by PCR using forward and reverse primers according to Balogh et al. (2009). The polymerase chain reaction was performed in a $25 \mu$ l reaction mixtures, containing: $1 \times$ PCR buffer $\left(\mathrm{NH}_{4}\right)_{2} \mathrm{SO}_{4}, 1.5 \mathrm{mM} \mathrm{MgCl}, 2 \mathrm{mM}$ dNTPs, 8 pM primers (Generi-Biotech), 1 U Tag DNA polymerase (Fermentas) and $50 \mathrm{ng}$ genomic DNA. Thermal cycling conditions included: an initial denaturation step at $94^{\circ} \mathrm{C}$ for $1 \mathrm{~min}$, followed by 30 cycles of $94^{\circ} \mathrm{C}$ for $30 \mathrm{sec}$, $53^{\circ} \mathrm{C}$ for $30 \mathrm{sec}, 72^{\circ} \mathrm{C}$ for $30 \mathrm{sec}$ and a final extension at $72^{\circ} \mathrm{C}$ for $5 \mathrm{~min}$.

PCR products of bovine genes were digested with FastDigest restriction enzymes: $\mathrm{GH}$ gene $-1 \mu \mathrm{l}$ AluI, LEP gene - $1 \mu \mathrm{l}$ Sau3AI and LEPR gene $-1 \mu \mathrm{l}$ Bse$\mathrm{GI}$ at $37^{\circ} \mathrm{C}$ in time $10 \mathrm{~min}$. The digestion products were separated by horizontal electrophoresis in 3\% agarose gels in $0.5 \times$ TBE $(130 \mathrm{~V}$ for $40 \mathrm{~min})$ stained with GelRed (Biotium) prior to visualization under UV light.

Statistical analysis. The allele and genotype frequencies of LEP, LEPR and GH genes were estimated by direct counting and the differences of the observed and expected frequencies of genotypes were tested using Chi-square $\left(\chi^{2}\right)$ test in order to verify if the population was in Hardy-Weinberg equilibrium. Genetic indices of populations, including observed and expected genes heterozygosity (He), homozygosity (Ho), effective allele numbers (Ne) and fixation indexes (FIS, FIT, FST) were performed by Popgene32 software version 1.3 (Yeh et al., 2000). Moreover, polymorphism information content (PIC) was calculated according to Botstein et al. (1980). The genetic distances Ds and $\mathrm{Da}$ between two breeds based on the frequency of alleles were calculated using the GeneticDistance software (Kalinowski, 2002) according to Nei's methods (Nei, 1978; Nei, 1987).

\section{RESULTS}

In Table 2 are presented frequencies of individual alleles and genotypes in the analyzed populations of Slovak Spotted cows. The highest frequencies were observed for LEP/Sau3AIAA, LEPR/T945MCC and GH/AluILL homozygotes, lower for heterozygous LEP/Sau3AIAB, LEPR/T945MCT and GH/AluILV genotypes, and lowest for the homozygous LEP/Sau3AIBB and GH/AluIVV genotypes. LEPR/T945MT'T homozygous genotype was not detected in analyzed group of cows. Populations of Slovak Spotted cows were in Hardy-Weinberg equilibrium $(p>0.05)$. Only in one case Hardy-Weinberg disequilibrium was observed, caused by the differences between the observed and expected frequencies of $\mathrm{GH} /$ AluI genotypes.

The observed heterozygosity, effective allele numbers and polymorphism information content of SNPs LEP/Sau3AI, LEPR/T945M and GH/AluI in analyzed populations are presented in Table 3. According to the classification of polymorphic information content cows

Table 1. Sequence of the primers, size and region of the amplified fragments in PCR and observed genotypes with size of the digestion patterns

\begin{tabular}{|c|c|c|c|c|c|}
\hline Gene & Primer sequences & $\begin{array}{l}\text { Size } \\
(b p)\end{array}$ & Amplified region & $\begin{array}{l}\text { Genotype/Digestion } \\
\text { patterns (bp) }\end{array}$ & Reference \\
\hline LEP & $\begin{array}{l}\text { F 5' -TGG AGT GGC TTG TTA TIT TCT TCT- } 3^{\prime} \\
\text { R 5'-GTC CCC GCT TCT GGC TAC CTA ACT- } \text { 3' }^{\prime}\end{array}$ & 422 & intron 2 & $\begin{array}{l}\text { AA } 390,32 \\
\text { AB } 390,303,88,32 \\
\text { BB } 303,88,32\end{array}$ & Liefers et al. (2002) \\
\hline LEPR & $\begin{array}{l}\text { F 5'-ACTACAGATGCTCTACTTTGG-3' } \\
\text { R 5'-TGCTCCTCCTCAGTIT-3' }\end{array}$ & 197 & exon 20 & $\begin{array}{l}\text { CC } 130,67 \\
\text { CT } 130,93,67,37 \\
\text { TT } 93,67,37\end{array}$ & Almeida et al. (2008) \\
\hline $\mathrm{GH}$ & $\begin{array}{l}\text { F: 5'-CGGACCGTGTCTATGAGAAGCTGAAG-3' } \\
\text { R: 5'-GTTCTTGAGCAGCGCGTCGTCA-3' }\end{array}$ & 428 & exon 5 & $\begin{array}{l}\text { LL } 265,96,51,16 \\
\text { LV } 265,147,96,51,16 \\
\text { VV } 265,147,16\end{array}$ & Balogh et al. (2009) \\
\hline
\end{tabular}


Table 2. Genetic structure of analyzed populations of Slovak Spotted cows

\begin{tabular}{|c|c|c|c|c|c|c|}
\hline \multirow{2}{*}{ Population } & \multicolumn{3}{|c|}{ Genotype frequency } & \multicolumn{2}{|c|}{ Allele frequency } & \multirow{2}{*}{$\underset{\text { test }}{\mathrm{X}^{2}}$} \\
\hline & LEP/Sau3AIAA & LEP/Sau3AIAB & LEP/Sau3AIBB & LEP/Sau3AIA & LEP/Sau3AIB & \\
\hline 1 & 0.69 & 0.29 & 0.02 & $0.8305 \pm 0.0244$ & $0.1695 \pm 0.0244$ & 0.044 \\
\hline 2 & 0.69 & 0.28 & 0.03 & $0.8276 \pm 0.0351$ & $0.1724 \pm 0.0351$ & 0.105 \\
\hline 3 & 0.58 & 0.38 & 0.04 & $0.7700 \pm 0.0421$ & $0.2300 \pm 0.0421$ & 0.200 \\
\hline 4 & 0.81 & 0.19 & - & $0.9071 \pm 0.0245$ & $0.0929 \pm 0.0245$ & 0.673 \\
\hline \multirow[t]{2}{*}{ Total } & 0.70 & 0.28 & 0.02 & $0.8378 \pm 0.0152$ & $0.1622 \pm 0.0152$ & 0.125 \\
\hline & LEPR/T945Mcc & LEPR/T945Mст & LEPR/T945M"T & LEPR/T945Mc & LEPR/T945M ${ }^{\top}$ & \\
\hline 1 & 0.89 & 0.11 & - & $0.9449 \pm 0.0149$ & $0.0551 \pm 0.0149$ & 0.344 \\
\hline 2 & 0.83 & 0.17 & - & $0.9138 \pm 0.0261$ & $0.0862 \pm 0.0261$ & 0.852 \\
\hline 3 & 0.92 & 0.08 & - & $0.9600 \pm 0.0196$ & $0.0400 \pm 0.0196$ & 0.174 \\
\hline 4 & 1 & - & - & 1.0000 & 0.0000 & - \\
\hline \multirow[t]{2}{*}{ Total } & 0.91 & 0.09 & - & $0.9544 \pm 0.0089$ & $0.0456 \pm 0.0089$ & 0.073 \\
\hline & GH/AlulLL & GH/Alulıv & GH/Alulvv & $\mathrm{GH} /$ Alul ${ }^{\mathrm{L}}$ & GH/Alulv & \\
\hline 1 & 0.46 & 0.47 & 0.07 & $0.7034 \pm 0.0297$ & $0.2966 \pm 0.0297$ & 2.097 \\
\hline 2 & 0.38 & 0.52 & 0.10 & $0.6379 \pm 0.0928$ & $0.3621 \pm 0.0928$ & 0.717 \\
\hline 3 & 0.38 & 0.60 & 0.02 & $0.6800 \pm 0.0466$ & $0.3200 \pm 0.0466$ & $6.835^{+}$ \\
\hline 4 & 0.61 & 0.33 & 0.06 & $0.7786 \pm 0.0351$ & $0.2214 \pm 0.0351$ & 0.209 \\
\hline Total & 0.48 & 0.46 & 0.06 & $0.7044 \pm 0.0188$ & $0.2956 \pm 0.0188$ & 0.021 \\
\hline
\end{tabular}

$-P>0.05,+P<0.05$

populations belonged to median or low polymorphism level (Table 3). Provided that the in biallelic system both alleles result in the genotypes creation is threshold value of $\mathrm{Ne} 2,000$. Comparison of loci $\mathrm{Ne}$ showed higher effective allele numbers across populations in locus $\mathrm{GH} /$ AluI (Table 3).

Table 3. Genetic diversity parameters evaluated in populations

\begin{tabular}{|c|c|c|c|c|}
\hline Population & $\mathrm{H}_{\mathrm{o}}$ & $\mathrm{H}_{\mathrm{e}}$ & $\mathrm{N}_{\mathrm{e}}$ & $\mathrm{PIC}$ \\
\hline \multicolumn{5}{|l|}{ LEP/Sau3AI } \\
\hline 1 & 0.7173 & 0.2827 & 1.3918 & 0.2431 \\
\hline 2 & 0.7121 & 0.2879 & 1.3993 & 0.2472 \\
\hline 3 & 0.6422 & 0.3578 & 1.5485 & 0.2951 \\
\hline 4 & 0.8303 & 0.1697 & 1.2026 & 0.1555 \\
\hline Total & 0.7230 & 0.2770 & 1.3731 & 0.2352 \\
\hline \multicolumn{5}{|l|}{ LEPR/T945M } \\
\hline 1 & 0.8955 & 0.1045 & 1.1162 & 0.0991 \\
\hline 2 & 0.8411 & 0.1589 & 1.1870 & 0.1465 \\
\hline 3 & 0.9224 & 0.0776 & 1.0832 & 0.0747 \\
\hline 4 & 1.0000 & 0.0000 & 1.0000 & 0.0000 \\
\hline Total & 0.9088 & 0.0912 & 1.0954 & 0.0800 \\
\hline \multicolumn{5}{|l|}{ GH/Alul } \\
\hline 1 & 0.5810 & 0.4190 & 1.7160 & 0.3319 \\
\hline 2 & 0.5340 & 0.4660 & 1.8586 & 0.3593 \\
\hline 3 & 0.5604 & 0.4396 & 1.7705 & 0.3449 \\
\hline 4 & 0.6527 & 0.3473 & 1.5262 & 0.2879 \\
\hline Total & 0.5304 & 0.4696 & 1.7136 & 0.3308 \\
\hline
\end{tabular}

Ho - observed homozygosity, $\mathrm{He}$ - observed heterozygosity, $\mathrm{Ne}-$ effective allele numbers; PIC — polymorphism information content
Observed Wright's fixation indexes (FIS and FIT) show negative value across SNPs (Table 4). These negative values represent slight excess of heterozygote compared with Hardy-Weinberg equilibrium expectations. These values observed for investigated markers suggest (values close to zero) a condition of equilibrium in the population as confirmed by the results of $\chi^{2}$ test used to verify Hardy-Weinberg equilibrium. The value of FST represents the degree of gene differentiation among populations in terms of allele's frequencies. In case of analyzed markers low differences between allele's frequencies in populations of cows were detected. The highest value was identified for marker GH/AluI (Table 4). Based on these results can be said, that the genetic differentiation between Slovak Spotted cows populations of different breeding is moderate. Nei's genetic distances were used to investigate genetic differences between Slovak Spotted cow's populations originating from four breeding. The low values of genetic distances (0.0018-0.0159) indicated high genetic relatedness among analyzed individuals.

\section{DISCUSSION}

Our results showed that analyzed populations of Slovak Spotted cows are in equilibrium for the detected markers. No evidence of inbreeding was found for all markers according to the results obtained from analysis

Table 4. Genetic variability of cows population based on F-statistic

\begin{tabular}{llll}
\hline Marker & $\mathrm{F}_{\text {IS }}$ & $\mathrm{F}_{\mathrm{IT}}$ & $\mathrm{F}_{\mathrm{ST}}$ \\
\hline LEP/Sau3AI & -0.09082 & -0.06848 & 0.02048 \\
\hline LEPR/T945M & -0.07772 & -0.05812 & 0.01819 \\
\hline GH/Alul & -0.05479 & -0.02979 & 0.02370 \\
\hline
\end{tabular}


of averaged FIS across populations, but this index does not directly detect inbreeding. However, an increase in the fraction of homozygotes (with a positive FIS) would be expected. FIS represents the average deviation of the population genotypic proportions from Hardy-Weinberg equilibrium for a locus. It is worth noting that FIS is not equivalent to the coefficient of inbreeding except the unlikely event that inbreeding alone is responsible for departures from Hardy-Weinberg equilibrium. A great similarity between populations of cows was shown by FST results based on the differences between allele's frequencies of analyzed markers. The comparatively low values of genetic distances between cow's populations may indicate, that the populations analysed originate from a common ancestor or inhabited neighbouring geographical regions and thus a frequent exchange of genes could take place. Similarities between examined populations could be caused also by the fact that their selection was conducted in a similar way (similar type of breeding program). For further studies should be carried out concerning LEP/Sau3AI, LEPR/T945M and GH/AluI polymorphisms in other dairy breeds in order to compare the allele frequencies and find for a possible relationship with the different production and reproduction traits. Finally, it is important to emphasize that SNPs could be investigated also as useful instruments for population studies.

\section{Acknowledgements}

This work has been supported by the Excellence Centre for Agrobiodiversity Conservation and Benefit project implemented under the Operational Programme Research and Development financed by European Fund for Regional Development (project number 26220120015) and by the Slovak Research and Development Agency under the contract No. APVV-0636-11 and LPP-022009.

\section{REFERENCES}

Almeida SEM, Santos LBS, Passos DT, Corbellini AO, Lopes BMT, Kirst C, Terra G, Neves JP, Goncalves PBD, Moraes JCF, Azevedo Weimer T (2008) Genetic polymorphsims at the leptin receptor gene in three beef cattle breeds. Genet Mol Biol 31: 680-685.

Balogh O, Kovács K, Kulcsár M, Gáspárdy A, Zsolnai A, Kátai L, Péci A, Fésüs L, Butler WR, Huszenicza G (2009) AluI polymorphism of the bovine growth hormone $(\mathrm{GH})$ gene, resumption of ovarian cyclicity, milk production and loss of body condition at the onset of lactation in dairy cattle. Theriogenology 71: 553-559.

Botstein D, White RL, Skolnik M, Davis RW (1980) Construction of a genetic linkage map in man using restriction fragment length polymorphism. Amer J Hum Genet 32: 314-331.

Kalinowski S (2002) Evolutionary and statistical properties of three genetic distances. Molecular Ecology 11: 1263-1273.

Leury BJ, Baumgard LH, Block SS, Segoale N, Ehrhardt RA, Rhoads RP, Bauman DE, Bell AW, Boisclair YR (2003) Effect of insulin and growth hormone on plasma leptin in periparturient dairy cows. Am J Physiol Regul Integr Comp Physiol 285: 1107-1115.

Liefers SC, Pas MFW, Veerkamp RF, Van der Lende T (2002) Associations between leptin gene polymorphisms and production, live weight, energy balance, feed intake, and fertility in Holstein heifers. J Dairy Sci 85: 227-238.

Liefers SC, Veerkamp RW, Te Pas MFW, Delavaud C, Chilliard Y, Van der Lende T (2004) A missense mutation in the bovine leptin receptor gene is associated with leptin concentrations during late pregnancy. Anim Genet 35: 138-141.

Lucy MC, Hauser SD, Eppard PJ, Krivi GG, Clark JH, Bauman DE, Colier RJ (1993) Variants of somatotropin in cattle: gene frequencies in major dairy breeds and associated milk production. Domest Anim Endocrinol 10: 325-333.

Nei M (1978) Estimation of average heterozygosity and genetic distance from a small number of individuals. Genetics 89: 583-590.

Nei M (1987) Molecular Evolutionary Genetics. Columbia University Press, New York, USA

Nicoll CS, Mayer GL, Russell SM (1986) Structural features of prolactin and growth hormones that can be related to their biological properties. Endocrinology Revue 7: 169-203.

Silva LFP, Van der Haar MJ, Weber Nielsen MS, Smith GW (2002) Evidence for a local effect of leptin in bovine mammary gland. $J$ Anim Sci 85: 3277-3286.

Stone RT, Kappes SM, Beattie CW (1996) The bovine homology of the obese gene maps to chromosome 4. Mammalian Genome 7: 399400 .

Svennersten-Sjaunja K, Olsson K (2005) Endocrinology of milk production. Domest Anim Endocrinol 29: 241-258.

Tartaglia LA (1997) The leptin receptor. J Biol Chem 272: 6093-6096.

Yeh FC, Yang R, Boyle TJ, Ye Z, Xiyan JM (2000) PopGene32, Microsoft Windows-based freeware for population genetic analysis, version 1.32. Mol. Biol. Biotechnol. Centre, Univ. Alberta, Edmonton, Alberta, Canada.

Zhang Y, Proenca R, Maffey M, Barone M, Leoppld L, Friedman JM (1994) Positional cloning of the mouse obese gene and its human homologue. Nature 372: 425-432. 